\title{
Examining Relations of Aggressive Communication in Social Networks
}

\author{
Alexandra Bekiari, Stergiani Deliligka, Athanasios Koustelios \\ Department of Physical Education and Sports, University of Thessaly, Volos, Greece \\ Email: sandrab@pe.uth.gr
}

How to cite this paper: Bekiari, A., Deliligka, S. and Koustelios, A. (2017) Examining Relations of Aggressive Communication in Social Networks. Social Networking, 6, 38-52.

http://dx.doi.org/10.4236/sn.2017.61003

Received: November 30, 2016

Accepted: December 27, 2016

Published: December 30, 2016

Copyright (๑) 2017 by authors and Scientific Research Publishing Inc. This work is licensed under the Creative Commons Attribution International License (CC BY 4.0).

http://creativecommons.org/licenses/by/4.0/

c) (i) Open Access

\begin{abstract}
Aim of this research is the detection of aggressive communication parameters and typology. A network sample of 62 students (male $=32$, female $=30)$ and 4 instructors (male $=2$, female $=2$ ) at the physical education and sport sciences dept. at the University of Thessaly has been collected in 2016. A standardized questionnaire consisting of network and non-network part was used. Social network analysis (algebraic analysis) combined with conventional statistics has been used. Basic results are the following ones: Persons dedicated to sport appear to target others and be targeted. Dedication to study content is proved to play a role of a refuge against criticism. High grade and ambition seem to protect against negative comments. Physical qualification (tallness) seems also to discourage rudeness. Spatial-regional discrimination is also revealed. Mockery seems to be even a cause of absence from the courses. A superiorityinduced aggressiveness (on economic basis) has been detected. Threat may be regarded as a behavioral extension of mockery (or inversely). In the course of study time, more aggressive persons emerge who even threat others. High grade students are unattractive for arguing. Internet seems to develop communication stimuli. The tendency for professional distinction is connected with arguing. Younger students show an integration deficit in terms of argumentation. Communicational types (three profiles of targets: "depreciated assaulted", "attractive", "repellent", and two profiles of general involvement: "lively", "controversial") have emerged. A typology of targets is depicting a sharper fragmentation than a typology of general involvement (targeted and acting).
\end{abstract}

\section{Keywords}

Verbal Aggressiveness, Argumentativeness, Social Networks, Physical Education Students 


\section{Introduction}

\subsection{Verbal Aggressiveness}

Aggressive intentions are prevalent in communicational interactions [1] [2]. Through verbal aggressiveness, the development of polite discussions among large groups and organizations is compromised, causing conflict and finally a possible failure [3]. Verbal aggressiveness is a person's tendency to attack the interlocutor's self-perception [4] [5]. Such aggressiveness constitutes part of an individual's personality [6] [7], although it is also the result of the environmental conditions where the individual acts [5]. Verbal aggressiveness consists of attacks on the character, the ability, in appearance and in the background, contempt, ridicule, threats, profanity, curses, loud voices, teasing gestures [4] [8][14]. When students receive verbal aggressiveness from their instructors, they indicate lower levels of motivation, satisfaction, rapport with the instructors and a more hostile learning environment [15]-[28] that is not conducive to attendance and class climate [29] [30] and interpersonal communication between students and instructors [31]-[36]. Also, research has shown that instructors' verbal aggressiveness is negatively correlated with affective learning [37] [38], interpersonal attractiveness [39] [40], fair play behaviors [41] of students, as they avoid asking questions and do not try to maintain the communication outside of the classroom [30].

\subsection{Argumentativeness}

The structure of human society, both in public and private sphere, consists of the essential features of dispute and argument [42]. Argumentativeness constitutes an individual's predisposition to oppose its opinions on controversial issues while trying to refute the positions of respondents [5] [43] [44]. [5] have pointed out that argumentative communication "is essential in a democratic society" (p. 320). [45] support that all persons have developed ability to use arguments. In the educational context, in cases when students perceive their instructors as argumentative, they are positively motivated to learn [46]. Argumentativeness is positively correlated with social, physical and task attraction [39], intrinsic reasons for discipline [47] and affective learning [48]. Also, students detect traits of assertiveness, intimacy and competence on argumentative instructors [27] as well as efficiency, sociability [39] and reliability [35]. Argumentativeness is positively correlated with positive classroom climate and emotional learning [25]. As noted by many studies [49]-[54], educational activities that promote argumentativeness are crucial for achieving the learning goals. Argumentativeness takes effect on students' comprehension of teaching concepts [55] [56].

\subsection{Innovation of the Research}

In general, the expected innovation of this research consists in quantifying results algebraically and statistically combined, depicting deeper and informal hierarchies of verbal aggressiveness and argumentativeness. In this way, personal 
determinants of positioning in such hierarchies are detected. The overview on several determinants of aggressiveness and argumentativeness is supposed to constitute a practical added value of this paper while the exploration of argumentativeness and aggressiveness using algebraic indicators of network theory constitutes the academic added value of the research.

\section{Method}

In 2016, a network sample of students class at the dept. of physical education and sport sciences of the University of Thessaly, Central Greece, has been collected. The sample consisted of a class at the $4^{\text {th }}$ semester. The students were 62 $($ male $=32$, female $=30)$ and 4 instructors $($ male $=2$, female $=2)$. This was a judgment and not a random sample, as the purpose was the analytic and not the descriptive statistics. The researchers had guaranteed to the participants that their names will remain secret in order to increase the probability to obtain sincere answers. The network questionnaire was strongly based on previous concept [39] [57]. Nevertheless, it was strengthened by the approach of [58] and [59] [60] regarding social power. Thereby, questions concerning verbal aggressiveness and argumentativeness were added. The non-network part included classical personal-social parameters related to the individual profile of students (e.g. age, family, social-economic state).The basic network variables (degree, in degree, Katz status, pagerank, authority) were calculated by Visone 1.1. Spearman test between non-network and network variables has been applied for revealing correlations. Principal Component Analysis between has also been applied between network variables for suggesting a typology. Spearman test has been preferred to multivariate analysis, because it enables an overview on all relations [59] [61] [62] [63].

\section{Results and Discussion}

In Figure 1, examples of networks of verbal aggressiveness and argumentativeness networks are presented. The network of avoiding argumentation is the

Relation
Circle form
$\begin{aligned} & \text { Nodes }=66, \\ & \text { Links }=120, \\ & \text { Density }=2.8 \%\end{aligned}$
$\begin{aligned} & \text { Modes }=66, \\ & \text { Links }=21, \\ & \text { Density }=0.5 \%\end{aligned}$

Figure 1. Examples of verbal aggressiveness and argumentativeness networks. 
densest $(2.8 \%)$ while this of mockery relations is the less dense one $(0.5 \%)$. This is understandable, as the avoiding argumentation is an easy solution in the everyday life in order to restrict misunderstanding and conflicts. On the other hand, mockery is normally practiced only among people familiar to each other and not from all to all. Thereby, it remains a quite rare relation within a group. Beyond density, the Katz, pagerank and authority have been depicted. Particularly, the authority of avoiding argumentation is a quite peculiar and unusual one, as it clearly obtains the structure of inverse pyramid. This is understandable as most nodes tend to posses the "distinct" position in avoidance.

In Table 1, instructors and persons who consider themselves to inspire interest in sport show the stronger degree of negative comments. This is understandable, as instructors have the duty of critically evaluating others and subsequently becoming unpleasant and targets of criticism as well. Persons who inspire sport interest also become a target because of jealousness and simultaneously, keep a critical attitude towards persons who do not take seriously the sport study and career. Those who become target of negative comments maintain the course content itself as a crucial basis of continuing to be interested, as the school milieu is perceived as hostile and cannot be an attractive pole for them. In this way, the study itself becomes a refuge for these persons. This fact implies that the study curriculum looks substantial enough to cover socialization deficits. Finally, those who are diligent or able enough to have achieved high grade or are ambitious enough to desire a professional career seem to discourage negative comments against them. This discloses that a spirit of academic respectfulness is cultivated at the physical education department.

In Table 2, as discussed in the previous tables, instructors seem once again to be susceptible to be rude. However, they do not become a target of rudeness because rudeness is de facto externalized to the target. Thus, students can hardly demonstrate such a behavior to the instructors. Tall students tend also not to

Table 1. Negative comments.

\begin{tabular}{|c|c|c|c|c|c|}
\hline & $\begin{array}{c}\text { Negative_comments_ } \\
\text { 9_degree }\end{array}$ & $\begin{array}{c}\text { Negative_comments_ } \\
\text { 9_indegree }\end{array}$ & $\begin{array}{c}\text { Negative_comments_ } \\
\text { 9_status }\end{array}$ & $\begin{array}{c}\text { Negative_comments_ } \\
\text { 9_pagerank }\end{array}$ & $\begin{array}{c}\text { Negative_comments_ } \\
\text { 9_authority }\end{array}$ \\
\hline \multirow[t]{2}{*}{ Student $=0$, instructor $=1$} & $0.403(* *)$ & -0.007 & -0.013 & -0.020 & 0.153 \\
\hline & 0.001 & 0.958 & 0.915 & 0.874 & 0.221 \\
\hline \multirow[t]{2}{*}{ Grade } & 0.098 & -0.080 & -0.073 & -0.043 & $-0.319\left(^{*}\right)$ \\
\hline & 0.535 & 0.616 & 0.647 & 0.789 & 0.039 \\
\hline \multirow[t]{2}{*}{ Inspiring interest in sports } & $0.319\left(^{*}\right)$ & -0.149 & -0.143 & -0.155 & -0.168 \\
\hline & 0.031 & 0.325 & 0.342 & 0.303 & 0.264 \\
\hline \multirow[t]{2}{*}{$\begin{array}{l}\text { Desire for distinction } \\
\text { as a professional }\end{array}$} & -0.124 & -0.268 & -0.252 & -0.257 & $-0.382\left(^{*}\right)$ \\
\hline & 0.434 & 0.086 & 0.108 & 0.101 & 0.012 \\
\hline \multirow[t]{2}{*}{ Interested in the subject } & 0.251 & $0.410(* *)$ & $0.408(* *)$ & $0.407(* *)$ & 0.184 \\
\hline & 0.092 & 0.005 & 0.005 & 0.005 & 0.222 \\
\hline
\end{tabular}

${ }^{*}$ Correlation is significant at the 0.01 level (2-tailed); Correlation is significant at the 0.05 level (2-tailed). 
Table 2. Rudeness.

\begin{tabular}{|c|c|c|c|c|c|c|}
\hline & Rude_14_degree & Rude_14_indegree & Rude_14_outdegree & Rude_14_status & $\begin{array}{l}\text { Rude_14_- } \\
\text { page rank }\end{array}$ & $\begin{array}{l}\text { Rude_14_ } \\
\text { authority }\end{array}$ \\
\hline \multirow[t]{2}{*}{ Student $=0$, instructor $=1$} & 0.230 & 0.000 & $0.348(* *)$ & -0.007 & 0.009 & -0.080 \\
\hline & 0.063 & 10.000 & 0.004 & 0.957 & 0.942 & 0.522 \\
\hline \multirow[t]{2}{*}{ Height } & $-0.375\left(^{*}\right)$ & $-0.389(* *)$ & -0.220 & $-0.391(* *)$ & $-0.363(*)$ & -0.286 \\
\hline & 0.010 & 0.008 & 0.141 & 0.007 & 0.013 & 0.054 \\
\hline \multirow[t]{2}{*}{ Rural residence } & $0.405(* *)$ & $0.371\left(^{*}\right)$ & 0.283 & $0.388(* *)$ & $0.356\left(^{*}\right)$ & 0.245 \\
\hline & 0.005 & 0.011 & 0.057 & 0.008 & 0.015 & 0.101 \\
\hline \multirow[t]{2}{*}{ Urban residence } & $-0.405(* *)$ & $-0.371\left(^{*}\right)$ & -0.283 & $-0.388(* *)$ & $-0.356\left(^{*}\right)$ & -0.245 \\
\hline & 0.005 & 0.011 & 0.057 & 0.008 & 0.015 & 0.101 \\
\hline \multirow[t]{2}{*}{ Childhood in rural area } & $0.462(* *)$ & $0.412(* *)$ & $0.330\left(^{*}\right)$ & $0.436(* *)$ & $0.422(* *)$ & 0.156 \\
\hline & 0.001 & 0.004 & 0.025 & 0.002 & 0.004 & 0.300 \\
\hline \multirow[t]{2}{*}{ Childhood in urban area } & $-0.462(* *)$ & $-0.412(* *)$ & $-0.330\left(^{*}\right)$ & $-0.436(* *)$ & $-0.422(* *)$ & -0.156 \\
\hline & 0.001 & 0.004 & 0.025 & 0.002 & 0.004 & 0.300 \\
\hline \multirow[t]{2}{*}{$\begin{array}{l}\text { Using internet } \\
\text { for entertainment }\end{array}$} & -0.223 & 0.205 & $-0.363\left(^{*}\right)$ & 0.204 & 0.204 & 0.108 \\
\hline & 0.137 & 0.172 & 0.013 & 0.173 & 0.174 & 0.477 \\
\hline
\end{tabular}

${ }^{* *}$ Correlation is significant at the 0.01 level (2-tailed); ${ }^{*}$ Correlation is significant at the 0.05 level (2-tailed).

become a target of rudeness, as tallness is a respectful and possibly awful qualification in physical education. It is, however, remarkable that the tall students do not show any clear susceptibility to be rude to others. Thus, if this is not attributed to tallness complex, then tallness seems to be so well integrated in a harmonious value system in physical education that seems to be connected with self-control. Rudeness seems to be related to regional determinants. This reveals a spatial discrimination, as people staying tend to be targeted for rude behavior and, also they exchange rudeness mutually (positive correlation to degree). However, being rude (outdegree) is a characteristic of a student originating from rural area rather than of a student being actually a resident of rural area. Thus, from a regional point of view, rudeness seems rather to be an aftermath of childhood-related setting and influence than an effect of actual milieu. The use of internet for reasons of entertainment seems to restrict the practicing of verbal aggressiveness in reality, as internet provides many options for relaxing (e.g. by listening music) or abreacting (e.g. let off outbursts in games or in chats). In this way, internet users have the chance to calm down in front of the computer and show a more sociable behavior in the everyday life.

In Table 3, mockery seems to be a cause of absence from the courses. It is natural that someone avoids attending the courses in order to avoid becoming a target of mockery. Moreover, the economic state of the family appears to be a basis of superiority-induced aggressiveness. Nevertheless, such a superiority-induced mockery does not remain without reaction: students of high economic state tend not only to mock others but also to become a target of mock- 
Table 3. Mockery.

\begin{tabular}{cccccc}
\hline & Mock_15_degree & Mock_15_indegree & Mock_15_outdegree & Mock_15_status & Mock_15_pagerank \\
\hline Non-attendance of courses & 0.202 & $\mathbf{0 . 3 0 9}\left(^{*}\right)$ & -0.080 & $\mathbf{0 . 3 0 5}\left(^{*}\right)$ & $\mathbf{0 . 3 3 4}\left(^{*}\right)$ \\
Family's economic state & 0.200 & $\mathbf{0 . 0 4 6}$ & 0.615 & $\mathbf{0 . 0 5 0}$ & $\mathbf{0 . 0 3 0}$ \\
& $\mathbf{0 . 4 6 1 ( * )}$ & 0.279 & $\mathbf{0 . 3 9 6}\left(^{* *}\right)$ & 0.277 & $\mathbf{0 . 3 0 5}\left(^{*}\right)$ \\
& $\mathbf{0 . 0 0 1}$ & 0.061 & $\mathbf{0 . 0 0 7}$ & 0.062 & $\mathbf{0 . 0 3 9}$ \\
\hline
\end{tabular}

${ }^{*}$ Correlation is significant at the 0.01 level (2-tailed); ${ }^{*}$ Correlation is significant at the 0.05 level (2-tailed).

ery. This may be attributed to the fact that mockery is often perceived as an intellectual interplay, which is relatively acceptable from anyone. Thus, a similar reaction to mockery is also acceptable as an intellectual challenge.

The "threat" seems to be an instructors' means. From the instructors' viewpoint, however, this may be perceived as simple "warning" ("if you don't learn this correctly, you will fail the exams"). The afore-mentioned findings about the relation of being instructor and the regionality (rural vs. urban) are supported once again in the case of threat (Table 4). Additionally, students of higher semester feel well established within groups of friends. They also have tested their influence. Subsequently, they feel more comfortable to practice behaviors which are regarded by others as threatening. Similarly, these who have travelled abroad for sport reasons, feel also challengeable enough to practice behavior which is perceived by others as threatening. However, such a person also becomes a target of threats due to jealousness. On the contrary, the lack of experience of travelling abroad is discouraging for developing threatening behavior, as not having tested his social challenge ability. Finally, students showing interest in team sports tend to become target of threat, as a consequence of their involvement in activity of high competitiveness.

In Table 5, if one is an instructor seems to be rather undesirable for discussant and simultaneously reluctant to argue with others. This can be attributed to the fact that an instructor is often introvert and concentrated on his research interests and scientific approaches. Also, he may try to avoid being exposed to criticism. Students with high grade are rather unattractive for arguing, as they are regarded as strongly competent or self-contained and concentrated on their study interests. Persons who tend to spend time in internet are not unattractive for arguing. This is an evidence that internet is a source of communication stimuli. The same stands also for those who reveal a desire for professional distinction in future. They also are not unattractive for arguing, not only due to the discussion stimuli they provide but also due to the fact that they often are-or try to appear as-socially and/or intellectually challengeable.

In Table 6, though the instructors appeared to avoid and be avoided for arguing (s. Table 5), they show to be enthusiast and to inspire enthusiasm in argumentation. Thus, they seem to expect higher argumentation standards than they find within the class. The property (being instructor or student) has proved to be relevant for the aggressive behavior in previous papers [64] [65]. The younger a student is, the less enthusiasm for arguing he feels and he inspires to 
Table 4. Threat.

\begin{tabular}{|c|c|c|c|}
\hline & Threat_17_degree & Threat_17_outdegree & Threat_17_authority \\
\hline \multirow{2}{*}{ Student $=00$. instructor $=1$} & 0.177 & $0.280\left(^{*}\right)$ & 0.147 \\
\hline & 0.155 & 0.023 & 0.239 \\
\hline \multirow[t]{2}{*}{ Rural residence } & 0.210 & $0.367\left(^{*}\right)$ & 0.220 \\
\hline & 0.161 & 0.012 & 0.143 \\
\hline \multirow[t]{2}{*}{ Urban residence } & -0.210 & $-0.367\left(^{*}\right)$ & -0.220 \\
\hline & 0.161 & 0.012 & 0.143 \\
\hline \multirow[t]{2}{*}{ Childhood in rural area } & $0.334\left(^{*}\right)$ & $0.450(* *)$ & $0.316(*)$ \\
\hline & 0.023 & 0.002 & 0.032 \\
\hline \multirow[t]{2}{*}{ Childhood in urban area } & $-0.334\left(^{*}\right)$ & $-0.450(* *)$ & $-0.316\left(^{*}\right)$ \\
\hline & 0.023 & 0.002 & 0.032 \\
\hline \multirow[t]{2}{*}{ Semester } & 0.186 & $0.318\left(^{*}\right)$ & -0.043 \\
\hline & 0.238 & 0.040 & 0.785 \\
\hline \multirow[t]{2}{*}{ Travelling for athletic reasons } & $0.308\left(^{*}\right)$ & 0.281 & 0.215 \\
\hline & 0.037 & 0.058 & 0.151 \\
\hline \multirow[t]{2}{*}{ Never travelled } & -0.192 & $-0.324\left(^{*}\right)$ & -0.033 \\
\hline & 0.201 & 0.028 & 0.829 \\
\hline \multirow[t]{2}{*}{ Interested in team sports } & 0.218 & 0.171 & $0.295\left(^{*}\right)$ \\
\hline & 0.146 & 0.257 & 0.046 \\
\hline
\end{tabular}

${ }^{*}$ Correlation is significant at the 0.01 level (2-tailed); ${ }^{*}$ Correlation is significant at the 0.05 level (2-tailed).

Table 5. Avoiding to argue.

\begin{tabular}{|c|c|c|c|c|c|c|}
\hline & $\begin{array}{c}\text { Avoid_argue_ } \\
\text { 18_degree }\end{array}$ & $\begin{array}{c}\text { Avoid_argue } \\
\text { 18_indegree }\end{array}$ & $\begin{array}{c}\text { Avoid_argue } \\
\text { 18_outdegree }\end{array}$ & $\begin{array}{c}\text { Avoid_argue } \\
\text { 18_status }\end{array}$ & $\begin{array}{c}\text { Avoid_argue_ } \\
\text { 18_pagerank }\end{array}$ & $\begin{array}{c}\text { Avoid_argue_ } \\
\text { 18_authority }\end{array}$ \\
\hline \multirow[t]{2}{*}{ Student $=0$, instructor $=1$} & $0.247\left(^{*}\right)$ & -0.013 & $0.372(* *)$ & 0.065 & 0.108 & -0.222 \\
\hline & 0.046 & 0.919 & 0.002 & 0.606 & 0.390 & 0.073 \\
\hline \multirow[t]{2}{*}{ Grade } & 0.254 & $0.334(*)$ & 0.108 & 0.294 & $0.320\left(^{*}\right)$ & $0.342\left(^{*}\right)$ \\
\hline & 0.105 & 0.031 & 0.494 & 0.059 & 0.039 & 0.027 \\
\hline \multirow[t]{2}{*}{$\begin{array}{l}\text { Spending time } \\
\text { in the internet }\end{array}$} & -0.150 & -0.288 & -0.022 & -0.287 & $-0.330\left(^{*}\right)$ & -0.285 \\
\hline & 0.319 & 0.052 & 0.884 & 0.053 & 0.025 & 0.055 \\
\hline \multirow[t]{2}{*}{$\begin{array}{l}\text { Desire for distinction } \\
\text { as a professional }\end{array}$} & $-0.323\left(^{*}\right)$ & $-0.339\left(^{*}\right)$ & -0.123 & $-0.372\left(^{*}\right)$ & $-0.371\left(^{*}\right)$ & -0.135 \\
\hline & 0.037 & 0.028 & 0.437 & 0.015 & 0.016 & 0.396 \\
\hline
\end{tabular}

${ }^{* *}$ Correlation is significant at the 0.01 level (2-tailed); ${ }^{*}$ Correlation is significant at the 0.05 level (2-tailed).

others. This is an evidence of not instant integration of a young student in the climate or the mentality of the study milieu. Just as in the case of instructors, so the students with high grade show enthusiasm for arguing, as they desire to test their state of knowledge and intellectual capacity. However, these who desire to 
be distinct as students or professionals are rather not inspiring to others enthusiasm for arguing. This may be attributed to the fact that they either are immoderately ambitious and challengeable or vain and provocative.

In Table 7, the instructors seem to enjoy arguing with others but the others do not enjoy arguing with them. This can be regarded as a lack of empathy in the part of instructors. The younger students seem not to enjoy arguing with others and these who desire to achieve professional distinction seem not to inspire others enjoyment for arguing with them for reasons similar to these described in Table 1.

In Table 8, three types of targets are revealed: a) the "depreciated assaulted", b) the "attractive", and c) the "repellent". The "depreciated assaulted" is a type who is verbally aggressed in multifarious ways (negative comments, rudeness, mockery and even threat). Simultaneously, others tend to avoid argue with him, though they tend to assault him. Thus, they seem to use him as target, but

Table 6. Enthusiasm to argue.

\begin{tabular}{|c|c|c|c|c|c|c|}
\hline & $\begin{array}{c}\text { Argue_ } \\
\text { enthusiasm_ } \\
\text { 19_degree }\end{array}$ & $\begin{array}{c}\text { Argue_- } \\
\text { enthusiasm_ } \\
\text { 19_indegree }\end{array}$ & $\begin{array}{c}\text { Argue_ } \\
\text { enthusiasm_ } \\
\text { 19_outdegree }\end{array}$ & $\begin{array}{c}\text { Argue_ } \\
\text { enthusiasm_ } \\
\text { 19_status }\end{array}$ & $\begin{array}{c}\text { Argue_ } \\
\text { enthusiasm_- } \\
\text { 19_pagerank }\end{array}$ & $\begin{array}{c}\text { Argue__ } \\
\text { enthusiasm_ } \\
\text { 19_authority }\end{array}$ \\
\hline \multirow[t]{2}{*}{$\begin{array}{c}\text { Student }=0 \\
\text { instructor }=1\end{array}$} & $0.355\left(^{* *}\right)$ & 0.182 & $0.407\left(^{* *}\right)$ & 0.176 & 0.178 & $0.255\left(^{*}\right)$ \\
\hline & 0.003 & 0.144 & 0.001 & 0.157 & 0.153 & 0.039 \\
\hline \multirow[t]{2}{*}{ Birth year } & $-0.447\left(^{* *}\right)$ & -0.085 & $-0.541\left(^{* *}\right)$ & -0.088 & -0.122 & -0.067 \\
\hline & 0.002 & 0.578 & 0.000 & 0.566 & 0.424 & 0.664 \\
\hline \multirow[t]{2}{*}{ Grade } & 0.216 & -0.118 & $0.366\left(^{*}\right)$ & -0.115 & -0.073 & -0.138 \\
\hline & 0.169 & 0.458 & 0.017 & 0.468 & 0.647 & 0.384 \\
\hline \multirow[t]{2}{*}{$\begin{array}{l}\text { Desire for distinction } \\
\text { as a student }\end{array}$} & -0.183 & $-0.435(* *)$ & 0.063 & $-0.479(* *)$ & $-0.452(* *)$ & $-0.396(* *)$ \\
\hline & 0.247 & 0.004 & 0.692 & 0.001 & 0.003 & 0.009 \\
\hline \multirow[t]{2}{*}{$\begin{array}{l}\text { Desire for distinction } \\
\text { as a professional }\end{array}$} & -0.215 & $-0.358\left(^{*}\right)$ & 0.012 & $-0.347\left(^{*}\right)$ & -0.296 & $-0.419(* *)$ \\
\hline & 0.172 & 0.020 & 0.939 & 0.024 & 0.057 & 0.006 \\
\hline
\end{tabular}

${ }^{*}$ Correlation is significant at the 0.01 level (2-tailed); ${ }^{\star}$ Correlation is significant at the 0.05 level (2-tailed).

Table 7. Enjoying to argue.

\begin{tabular}{|c|c|c|c|}
\hline & $\begin{array}{l}\text { Enjoy_argue_ } \\
20 \_ \text {outdegree }\end{array}$ & $\begin{array}{c}\text { Enjoy_argue } \\
20 \_ \text {pagerank }\end{array}$ & $\begin{array}{c}\text { Enjoy_argue } \\
20 \_ \text {authority }\end{array}$ \\
\hline \multirow[t]{2}{*}{ Student $=0$, instructor $=1$} & $0.317\left(^{* *}\right)$ & 0.048 & $-0.417(* *)$ \\
\hline & 0.009 & 0.703 & 0.000 \\
\hline \multirow[t]{2}{*}{ Birth year } & $-0.369\left(^{*}\right)$ & -0.034 & 0.247 \\
\hline & 0.013 & 0.825 & 0.101 \\
\hline \multirow[t]{2}{*}{ Desire for distinction as a professional } & -0.004 & $-0.320\left(^{*}\right)$ & 0.035 \\
\hline & 0.980 & 0.039 & 0.827 \\
\hline
\end{tabular}

${ }^{*}$ Correlation is significant at the 0.01 level (2-tailed); ${ }^{*}$ Correlation is significant at the 0.05 level ( 2 -tailed). 
Table 8. Communicational types of target (received actions).

\begin{tabular}{ccccc}
\hline & & $\begin{array}{c}\text { "Depreciated } \\
\text { assaulted" }\end{array}$ & "Attractive" “Repellent" \\
\hline \multirow{2}{*}{$\begin{array}{c}\text { Verbal } \\
\text { aggressiveness }\end{array}$} & Negative_comments_9_sum & $\mathbf{0 . 8 4 6}$ & -0.093 & 0.092 \\
& Rude_14_sum & $\mathbf{0 . 5 8 1}$ & -0.059 & -0.618 \\
& Mock_15_sum & $\mathbf{0 . 4 3 2}$ & 0.090 & 0.296 \\
Argumentativeness & Threat_17_sum & $\mathbf{0 . 8 5 6}$ & -0.169 & -0.238 \\
& Avoid_argue_18_sum & $\mathbf{0 . 5 2 6}$ & -0.046 & $\mathbf{0 . 6 9 2}$ \\
& Argue_enthusiasm_19_sum & 0.146 & $\mathbf{0 . 9 5 8}$ & -0.013 \\
& Enjoy_argue_20_sum & 0.105 & $\mathbf{0 . 9 7 0}$ & -0.052 \\
\hline
\end{tabular}

Extraction Method: Principal Component Analysis. 3 components extracted.

they depreciate him as a discussant. This seems to be the profile of a strongly and adversely excluded student. This could be regarded as the antipode of integration. The "attractive" type is a person who is regarded by others as worth discussing with. They seem to enthusiastically expect to discuss with him and also to enjoy this discussion. At the same time, they do not tend to make him a target of verbal aggressiveness. Such a profile is obviously a quite ideal state in the communicational arena. Nevertheless, it proves to be realistic on the basis of these statistical results. Finally, the "repellent" is a type who just tends to discourage others from arguing with him. As this type does not appear to be targeted for aggression, such repellence is not an effect of depreciation. This repellence may be attributed to an inspiring or awesome impression. In general, the whole group seems to be fragmented in three quite different and clearly demarcated profiles of students which could be characterized as deplorable, adorable or even impressive. There is no profile combining common features. Thereby, the gap among these profiles seems to be unbridgeable. Such a group cannot be seen as a homogenous or united one.

In Table 9, two types of behavioral degree (general involvement) are presented. The "lively" type is a person who both is attacking and targeted for aggression of various forms (from comments to threat). However, at the same time, this person is not avoided for arguing but rather attracting others for an enthusiastic conversation as well as involved in discussions enthusiastically. Thus, the multifarious verbal aggressiveness which he exerts or incurs from others obtains a different state than this of mere oppression. It seems rather to become a continuous social or intellectual challenge. The "controversial" type shows a quite controversial synthesis. It depicts a person who, on the one hand, tends to avoid and simultaneously is avoided by others in the argumentation, and on the other hand, he tends to seek the exchange of arguments in enthusiastic and enjoyable climate. This behavioral controversy can be described as indecisiveness or as a courageous behavior afflicted, however, with inhibitions. It could be characterized as a rather normal everyday behavior (everyone would desire to develop or maintain a certain social state or dominance, but not fully free of any constraint or question about the correctness of his behavior). 
Table 9. Communicational types of involvement (degree).

\begin{tabular}{cccc}
\hline & & The "lively" & The "controversial" \\
\hline \multirow{2}{*}{$\begin{array}{c}\text { Verbal } \\
\text { aggressiveness }\end{array}$} & Negative_comments_9_degree & $\mathbf{0 . 8 3 6}$ & 0.167 \\
& Rude_14_degree & $\mathbf{0 . 8 6 1}$ & -0.120 \\
& Mock_15_degree & $\mathbf{0 . 7 0 3}$ & -0.196 \\
Argumentativeness & Threat_17_degree & $\mathbf{0 . 8 5 7}$ & -0.231 \\
& Avoid_argue_18_degree & 0.019 & $\mathbf{0 . 3 1 3}$ \\
& Argue_enthusiasm_19_degree & $\mathbf{0 . 3 0 3}$ & $\mathbf{0 . 7 8 7}$ \\
& Enjoy_argue_20_degree & 0.066 & $\mathbf{0 . 8 3 1}$
\end{tabular}

Extraction Method: Principal Component Analysis. 2 components extracted.

Such typology formulation has been made also in previous papers revealing profiles consisting of particular behaviors, attitudes or other characteristics [59]-[64] [66].

\section{Conclusions}

The afore-mentioned academic and practical added value is expected to be fulfilled to certain extent by the findings discussed above. Concisely, results concerning particular forms of aggressiveness and argumentation have been revealed. Rudeness is ascribed to instructors, who hence could pay more attention to the communication style. Dedication to sport leads to target others and be targeted. Dedication to study content proved to play a role of a refuge. High grade and ambition seem to be protective. Thus, these two elements could be considered as an unwritten but structured value system (organizational culture) at the physical education department. This value system consists not only of mental and social but also of physical dimensions as it is enhanced with physical qualifications (tallness) which seem to discourage rudeness. Spatial-regional and economic discrimination (urban vs. rural origin and residence) is also revealed. This can be considered for paying more attention to the communication style and to public relation with certain students groups as well as to the support of such discriminated student groups. Internet entertainment leads to restriction of rudeness. Thus, such a digital means could be used at the department at more organized level (e.g. in the intervals between courses) in order to improve the climate at the department. Mockery should be paid attention more than rudeness as it may even be a cause of absence from the courses. Threat shows features similar to these of mockery while a certain evolutionism in verbal aggressiveness in the course of study has been proved. This tendency of evolutionism which is further enhanced by social challenging and the team sports competitiveness should draw the attention of the instructors. Instructors and high grade students discourage argumentation. An antidote to exclusion of arguing seems to be internet use. The instructors and high grade students are also related with enthusiasm for arguing, though their abstention from arguing. Therefore, a gap between real and expected argumentation is obvious. Younger students show an 
integration deficit in terms of argumentation.

Communicational types have also been detected. More precisely, three profiles of targets ("depreciated assaulted", "attractive", "repellent") and two profiles of general involvement, namely being both targeted and acting ("lively", "controversial") have emerged. The three target types are so clearly demarcated that the whole network appears to be quite fragmented in fully different communicational milieus (from quite integrated to totally marginal). The two types of involvement seem to be not so clearly demarcated. They could be characterized as normal (everyday) behavioral patterns rather than as fully integrated or marginal. In general, a typology of targets is rather depicting a much sharper fragmentation than a typology of general involvement (targeted and acting). In other words, targeting induces gaps while acting seems to fix them up. This means more simply that mutuality of actions, even in case of verbal aggression, tends slightly to mitigate fragmentation more than passiveness (being targeted).

\section{References}

[1] Bekiari, A. and Hasanagas, N. (2016) Sociological Insights in the Education System: "Unlocking” the Power Relations. Afoi Kyriakidi Editions S.A., Thessaloniki.

[2] Bekiari, A. and Hasanagas, N. (2016) "Educating” in Physical Education. Theoretical Approaches and Practical Inquiries. Afoi Kyriakidi Editions S.A., Thessaloniki.

[3] Hamilton, M.A. (2012) Verbal Aggression Understanding the Psychological Antecedents and Social Consequences. Journal of Language and Social Psychology, 31, 5 12. https://doi.org/10.1177/0261927X11425032

[4] Infante, D.A. and Wigley III, C.J. (1986) Verbal Aggressiveness: An Interpersonal Model and Measure. Communications Monographs, 53, 61-69. https://doi.org/10.1080/03637758609376126

[5] Infante, D.A. and Rancer, A.S. (1996) Argumentativeness and Verbal Aggressiveness: A Review of Recent Theory and Research. Annals of the International Communication Association, 19, 319-352. https://doi.org/10.1080/23808985.1996.11678934

[6] Aloia, L.S. and Solomon, D.H. (2016) Emotions Associated with Verbal Aggression Expression and Suppression. Western Journal of Communication, 80, 3-20. https://doi.org/10.1080/10570314.2014.943428

[7] Goodboy, A.K. and Myers, S.A. (2012) Instructional Dissent as an Expression of Students' Verbal Aggressiveness and Argumentativeness Traits. Communication Education, 61, 448-458. https://doi.org/10.1080/03634523.2012.699635

[8] Infante, D.A., Sabourin, T.C., Rudd, J.E. and Shannon, E.A. (1990) Verbal Aggression in Violent and Nonviolent Marital Disputes. Communication Quarterly, 38, 361-371. https://doi.org/10.1080/01463379009369773

[9] Infante, D.A. (1987) Aggressiveness. In: McCroskey, J.C. and Daly, J.A., Eds., Personality and Interpersonal Communication, Sage, Newbury Park, 157-192.

[10] Infante, D.A., Riddle, B.L., Horvath, C.L. and Tumlin, S.A. (1992) Verbal Aggressiveness: Messages and Reasons. Communication Quarterly, 40, 116-126. https://doi.org/10.1080/01463379209369827

[11] Coyne, S.M. and Archer, J. (2004) Indirect Aggression in the Media: A Content Analysis of British Television Programs. Aggressive Behavior, 30, 254-271. https://doi.org/10.1002/ab.20022 
[12] Avtgis, T. and Rancer, A.S., Eds. (2010) Arguments, Aggression, and Conflict: New Directions in Theory and Research. Routledge, Abingdon-on-Thames.

[13] Neuman, J.H. and Baron, R.A. (1997) Aggression in the Workplace. In: Giacalone, R.A. and Greenberg, J., Eds., Antisocial Behavior in Organizations, Sage Publications, Inc., Thousand Oaks, 37-67.

[14] Rancer, A.S. and Avtgis, T.A. (2006) Argumentative and Aggressive Communication: Theory, Research, and Application. Sage Publications, Thousand Oaks.

[15] Bekiari, A. (2014) Verbal Aggressiveness and Leadership Style of Sports Instructors and their Relationship with Athletes' Intrinsic Motivation. Creative Education, 5, 114-121. https://doi.org/10.4236/ce.2014.52018

[16] Bekiari, A. (2016) Insights into Instructors' Verbal Aggressiveness and Students' Machiavellianism through Leadership Style and Motivational Climate. European Scientific Journal, 12, 90-110. https://doi.org/10.19044/esj.2016.v12n25p90

[17] Bekiari, A., Kokaridas, D. and Sakellariou, K. (2005) Verbal Aggressiveness of Physical Education Teachers and Students' Self-Reports of Behaviour. Psychological Reports, 96, 493-498.

[18] Bekiari, A., Kokaridas, D. and Sakellariou, K. (2006) Associations of Students' Self-Reports of Their Teacher's Verbal Aggression, Intrinsic Motivation, and Perceptions of Reasons for Discipline in Greek Physical Education Classes. Psychological Reports, 98, 451-461.

[19] Bekiari, A., Perkos, S. and Gerodimos, V. (2015) Verbal Aggression in Basketball: Perceived Coach Use and Athlete Intrinsic and Extrinsic Motivation. Journal of Physical Education and Sport, 15, 96-102.

[20] Bekiari, A. and Syrmpas, I. (2015) Coaches' Verbal Aggressiveness and Motivational Climate as Predictors of Athletes' Satisfaction. British Journal of Education, Society \& Behavioural Science, 9, 318-329. https://doi.org/10.9734/BJESBS/2015/17757

[21] Bekiari, A. and Tsiana, I. (2016) Exploring Instructors' Verbal Aggressiveness and Students' Personal Orientations and Reasons of Discipline in Physical Education Class. Advances in Physical Education, 6, 158-168. https://doi.org/10.4236/ape.2016.63018

[22] Manoli, P. and Bekiari, A. (2015) EFL Teachers' Verbal Aggressiveness and Students' Intrinsic Motivation and Social-Affective Strategy Use: Investigating Possible Relations. Advances in Research, 5, 1-13. https://doi.org/10.9734/AIR/2015/19692

[23] Mazer, J.P. and Stowe, S.A. (2016) Can Teacher Immediacy Reduce the Impact of Verbal Aggressiveness? Examining Effects on Student Outcomes and Perceptions of Teacher Credibility. Western Journal of Communication, 80, 21-37. https://doi.org/10.1080/10570314.2014.943421

[24] Teven, J.J. (2007) Teacher Caring and Classroom Behavior: Relationships with Student Affect and Perceptions of Teacher Competence and Trustworthiness. Communication Quarterly, 55, 433-450. https://doi.org/10.1080/01463370701658077

[25] Myers, S.A. and Knox, R.L. (2000) Perceived Instructor Argumentativeness and Verbal Aggressiveness and Student Outcomes. Communication Research Reports, 17, 299-309. https://doi.org/10.1080/08824090009388777

[26] Myers, S.A. and Rocca, K.A. (2001) Perceived Instructor Argumentativeness and Verbal Aggressiveness in the College Classroom: Effects on Student Perceptions of Climate, Apprehension, and State Motivation. Western Journal of Communication, 65, 113-137. https://doi.org/10.1080/10570310109374696

[27] Myers, S.A. (2002) Perceived Aggressive Instructor Communication and Student State Motivation, Learning and Satisfaction. Communication Reports, 15, 113-121. 
https://doi.org/10.1080/08934210209367758

[28] Snyder, J., Forbus, R. and Cistulli, M. (2012) Attendance Policies, Student Attendance, and Instructor Verbal Aggressiveness. Journal of Education for Business, 87, 145-151. https://doi.org/10.1080/08832323.2011.582192

[29] Rocca, K.A. (2004) College Student Attendance: Impact of Instructor Immediacy and Verbal Aggression. Communication Education, 53, 185-195. https://doi.org/10.1080/03634520410001682447

[30] Myers, S.A., Edwards, C., Wahl, S.T. and Martin, M.M. (2007) The Relationship between Perceived Instructor Aggressive Communication and College Student Involvement. Communication Education, 56, 495-508. https://doi.org/10.1080/03634520701466398

[31] Bekiari, A., Digelidis, N. and Sakellariou, K. (2006) Perceived Verbal Aggressiveness of Coaches in Volleyball and Basketball: A Preliminary Study. Psychological Reports, 103, 526-530.

[32] Bekiari, A., Patsiaouras, A., Kokaridas, D. and Sakellariou, K. (2006) The Relationship between Verbal Aggressiveness and State Anxiety in Volleyball. Psychological Reports, 99, 630-634.

[33] Bekiari, A. and Sakellariou, K. (2003) Perceived Instructor Verbal Aggressiveness and Student State Learning in Physical Education. Italian Journal of Sport Sciences, 1, 251-256.

[34] Edwards, C. and Myers, S.A. (2007) Perceived Instructor Credibility as a Function of Instructor Aggressive Communication. Communication Research Reports, 24, 47-53. https://doi.org/10.1080/08824090601128141

[35] Schrodt, P. (2003) Student Perceptions of Instructor Verbal Aggressiveness: The Influence of Student Verbal Aggressiveness and Self-Esteem. Communication Research Reports, 20, 240-250. https://doi.org/10.1080/08824090309388822

[36] Rocca, K.A. and McCroskey, J.C. (1999) The Interrelationship of Student Ratings of Instructors' Immediacy, Verbal Aggressiveness, Homophily, and Interpersonal Attraction. Communication Education, 48, 308-316. https://doi.org/10.1080/03634529909379181

[37] Bekiari, A. (2012) Perceptions of Instructors' Verbal Aggressiveness and Physical Education Students' Affective Learning. Perceptual and Motor Skills, 115, 325-335.

[38] Bekiari, A. and Tsaggopoulou, T. (2016) Verbal Aggressiveness and Affective Learning in Physical Education. Advances in Physical Education, 6, 406-418. https://doi.org/10.4236/ape.2016.64041

[39] Syrmpas, I. and Bekiari, A. (2015) The Relationship between Perceived Physical Education Teacher's Verbal Aggressiveness and Argumentativeness with Students' Interpersonal Attraction. Inquiries in Sport \& Physical Education, 13, 21-32.

[40] Bekiari, A. and Petanidis, D. (2016) Exploring Teachers' Verbal Aggressiveness through Interpersonal Attraction and Students' Intrinsic Motivation. Open Journal of Social Sciences, forthcoming.

[41] Hassandra, M., Bekiari, A. and Sakellariou, K. (2007) Physical Education Teacher's Verbal Aggression and Student's Fair Play Behaviors. The Physical Educator, 64, 94-101.

[42] Hample, D. and Anagondahalli, D. (2015) Understandings of Arguing in India and the United States: Argument Frames, Personalization of Conflict, Argumentativeness, and Verbal Aggressiveness. Journal of Intercultural Communication Research, 44, 1-26. https://doi.org/10.1080/17475759.2014.1000939

[43] Infante, D.A. and Rancer, A.S. (1982) A Conceptualization and Measure of Argu- 
mentativeness. Journal of Personality Assessment, 46, 72-80. https://doi.org/10.1207/s15327752jpa4601 13

[44] Rancer, A.S. and Avtgis, T.A. (2014) Argumentative and Aggressive Communication: Theory, Research, and Application. 2nd Edition, Peter Lang, New York.

[45] Mercier, H. and Sperber, D. (2011) Why Do Humans Reason? Arguments for an Argumentative Theory. Behavioral and Brain Sciences, 34, 57-74. https://doi.org/10.1017/S0140525X10000968

[46] Myers, S.A. and Rocca, K.A. (2000) The Relationship between Perceived Instructor Communicator Style, Argumentativeness, and Verbal Aggressiveness. Communication Research Reports, 17, 1-12. https://doi.org/10.1080/08824090009388745

[47] Bekiari, A. and Pylarinou, M. (2016) Instructor Argumentativeness and Socio-Communicative Style and Student Discipline: Using Physical Education Students' Class as an Illustration. Journal of Physical Education and Sport, forthcoming.

[48] Bekiari, A. and Manoli, P. (2016) EFL Teacher Verbal Aggressiveness and Argumentativeness and Student Socio-Affective Strategy Use and Affective Learning: Exploring Possible Associations. Journal of Teacher Education and Educators, 5, 154-171.

[49] Osborne, J., Simon, S., Christodoulou, A., Howell-Richardson, C. and Richardson, K. (2013) Learning to Argue: A Study of Four Schools and Their Attempt to Develop the Use of Argumentation as a Common Instructional Practice and Its Impact on Students. Journal of Research in Science Teaching, 50, 315-347.

https://doi.org/10.1002/tea.21073

[50] Knight, A.M. and McNeill, K.L. (2012) Comparing Students' Written and Verbal Scientific Arguments. Annual Meeting of the National Association for Research in Science Teaching, Indianapolis, IN.

[51] Dawson, V.M. and Venville, G. (2010) Teaching Strategies for Developing Students' Argumentation Skills about Socioscientific Issues in High School Genetics. Research in Science Education, 40, 133-148. https://doi.org/10.1007/s11165-008-9104-y

[52] Simon, S., Erduran, S. and Osborne, J. (2006) Learning to Teach Argumentation: Research and Development in the Science Classroom. International Journal of Science Education, 28, 235-260. https://doi.org/10.1080/09500690500336957

[53] Nussbaum, E.M. and Bendixen, L.D. (2003) Approaching and Avoiding Arguments: The Role of Epistemological Beliefs, Need for Cognition, and Extraverted Personality Traits. Contemporary Educational Psychology, 28, 573-595.

[54] Zembal-Saul, C., Munford, D., Crawford, B., Friedrichsen, P. and Land, S. (2002) Scaffolding Preservice Science Teachers' Evidence-Based Arguments during an Investigation of Natural Selection. Research in Science Education, 32, 437-463. https://doi.org/10.1023/A:1022411822951

[55] Clark, D.B. and Sampson, V.D. (2007) Personally-Seeded Discussions to Scaffold Online Argumentation. International Journal of Science Education, 29, 253-277. https://doi.org/10.1080/09500690600560944

[56] Duschl, R.A. and Osborne, J. (2002) Supporting and Promoting Argumentation Discourse in Science Education. Studies in Science Education, 38, 39-72. https://doi.org/10.1080/03057260208560187

[57] Bekiari, A. and Digelidis, N. (2015) Measuring Verbal Aggressiveness in Sport and Education. International Journal of Physical Education, 52, 12-21.

[58] Popitz, H. (1992) Phänomene der Macht. J.C.B. Mohr, Tuebingen.

[59] Bekiari, A. and Hasanagas, N. (2015) Verbal Aggressiveness Exploration through 
Complete Social Network Analysis: Using Physical Education Students' Class as an Illustration. International Journal of Social Science Studies, 3, 30-49. https://doi.org/10.11114/ijsss.v3i3.729

[60] Bekiari, A. and Hasanagas, N. (2016) Suggesting Indicators of Superficiality and Purity in Verbal Aggressiveness. An Application in Adult Education Class Networks of Prisoners. Open Journal of Social Sciences, 4, 279-292. https://doi.org/10.4236/jss.2016.43035

[61] Hasanagas, N. and Bekiari, A. (2015) Depicting Determinants and Effects of Intimacy and Verbal Aggressiveness Target through Social Network Analysis. Sociology Mind, 5, 162-175. https://doi.org/10.4236/sm.2015.53015

[62] Theoharis, D. and Bekiari, A. (2016) The Influence of Mathematics and Learning Environment in Verbal Aggressiveness and Interpersonal Relations: A Dynamic Analysis of Social Networks. Proceedings of the 8 th International Congress Mathematical Society, Thessaloniki, 30 March-3 April 2016.

[63] Theoharis, D. and Bekiari, A. (2016) Social Networks Analysis of Centrality: Case Study in Leadership Networks. Proceedings of the 33nd Congress Greek Mathematical Society (with International Participation), Chania, 4-6 November 2016, 250-260.

[64] Bekiari, A. and Spyropoulou, S. (2016) Exploration of Verbal Aggressiveness and Interpersonal Attraction through Social Network Analysis: Using University Physical Education Class as an Illustration. Open Journal of Social Sciences, 4, 145-155. https://doi.org/10.4236/jss.2016.46016

[65] Bekiari, A., Hasanagas, N., Theoharis, D., Kefalas, I. and Vasilou, A. (2015) The Role of Mathematical Object and the Educational Environment to Students' Interpersonal Relationships: An Application of Full Social Network Analysis. Proceedings of the 32 nd Congress Greek Mathematical Society (with International Participation), Kastoria, 799-812.

[66] Theoharis, D., Bekiari, A. and Koustelios, A. (2017) Exploration of Determinants of verbal Aggressiveness and Leadership through Network Analysis and Conventional Statistics. Using School Class as an Illustration. Sociology Mind, Forthcoming.

\section{Submit or recommend next manuscript to SCIRP and we will provide best service for you:}

Accepting pre-submission inquiries through Email, Facebook, LinkedIn, Twitter, etc. A wide selection of journals (inclusive of 9 subjects, more than 200 journals) Providing 24-hour high-quality service User-friendly online submission system Fair and swift peer-review system Efficient typesetting and proofreading procedure Display of the result of downloads and visits, as well as the number of cited articles Maximum dissemination of your research work

Submit your manuscript at: http://papersubmission.scirp.org/

Or contact sn@scirp.org 